\title{
Exploitation of endophytic Pseudomonas sp. for plant growth promotion and colonization in rice
}

\author{
Gurjot Kaur $^{1 *}$, Poonam Sharma², Deepika Chhabra', Kailash Chand ${ }^{1}$ and Gurjit Singh \\ Mangat $^{2}$ \\ ${ }^{1}$ Department of Microbiology, Punjab Agricultural University, Ludhiana-141004 (Punjab), INDIA \\ ${ }^{2}$ Department of Plant Breeding and Genetics, Punjab Agricultural University, Ludhiana-141004 (Punjab), INDIA \\ *Corresponding author. E-mail: gurjotkaur-cobsmb@pau.edu
}

Received: September 27, 2016; Revised received: February 27, 2017; Accepted: June 28, 2017

\begin{abstract}
The present investigation was carried out to exploit bacterial endophytes associated with root and leaf tissue of rice plant for plant growth promotion (PGP) and colonization study in vitro. Total 10 endophytic bacterial isolates (Pseudomonas sp.) were evaluate for PGP traits like P solubilization, production of Indole acetic acid (IAA), siderophore, ACC deaminase, protease, cellulase, fluorescent pigment, urease and denitrification activity. Out of 10 endophytic bacteria $30 \%, 60 \%, 20 \%, 70 \%, 10 \%$ and $10 \%$ were positive for siderophore, protease, cellulase, fluorescent pigment, urease and denitrification respectively. Maximum IAA production was recorded with isolate LRBLE7 $\left(18.8 \mathrm{\mu gml}^{-1}\right)$ followed by LRBRE4 $\left(16.0 \mathrm{\mu gml}^{-1}\right)$ and maximum P-solubilization was recorded with isolate

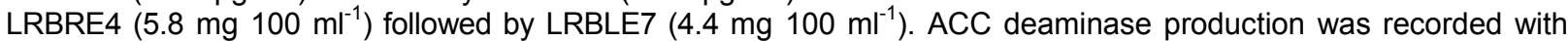
isolate LRBLE6 $(O . D=0.352 \mathrm{~nm}$ ) followed by LRBRE5 (O.D=0.324nm). Three potential isolates (LRBRE4, LRBRE6 and LRBLE7) were selected on the basis of multiple PGP traits and were subjected to colonization study of rice seedling in vitro. Potential bacterial isolates can be exploited for improving growth and productivity in rice under sustainable management system.
\end{abstract}

Keywords: Colonization, Endophytic bacteria, Plant growth promotion, Pseudomonas, Rice

\section{INTRODUCTION}

Plants are constantly involved in interaction with a wide range of bacteria. Plant associated bacteria colonize the rhizosphere (rhizobacteria), phyllosphere (epiphytes) and inside the plant tissues (endophytes). Endophytes are the microorganisms that do not visibly harmful to the plants and able to live inside the tissues for improving plant growth and sources of fertilization for host (Sessitsch et al., 2015). Endophytic bacteria (Pseudomonas, Corynebacterium, Caulobacter, Methylobacterium, Sphingomonas etc.) are ubiquitous distributed in most plant species either through their active colonization or as latent residents in plant tissues. The endophytic communities were mainly comprised of five phyla viz. Proteobacteria (90\%), Actinobacteria $(1.5 \%)$, Planctomycetes $(1.4 \%)$, Verrucomicrobia $(1.1 \%)$ and Acidobacteria $(0.5 \%)$. The commonly found bacterial endophytic genera are Pseudomonas, Bacillus, Burkholderia, Stenotrophomonas, Micrococcus, Pantoea and Microbacterium etc (Romero et al., 2014). Pseudomonas sp. has ability to utilize various nutrients present in root exudates is a key to the success as plant colonizers. Pseudomonas sp. is widespread bacteria in agricultural soils, has many traits that make them well matched as PGPR. Mainly, Pseudomonas sp was used for plant growth promotion and disease control in rice crop (Panhwar et al., 2012). Cellulase and protease act as key enzymes for the invasion and colonization of plant roots. Siderophore production and utilization by plant growth promoting endophytic bacteria (PGPEB) is important because of iron is essential in the nitrogen fixation and assimilation process. Iron is a major element required by various microorganisms for cellular processes such as electron transport chain and as a cofactor for many enzymes. Bacterial IAA increase root surface area and length and therefore provide the plant greater access to soil nutrients and water uptake. Bacterial IAA can obviate to a certain extent the function of ACC deaminase with siderophore and phosphate solubilizing ability. Plant growth promoting bacteria (PGPB) producing siderophores, effect the plant growth through direct or indirect mechanism under low iron conditions. Excretion of siderophores by rhizospheric bacteria stimulate plant growth either by improving Fe nutrition to plant or by making $\mathrm{Fe}$ unavailable to phytopathogens thus protecting plant from pathogen (Souza et al., 2013). Ethylene precursor ACC is degraded by the enzyme 1-Aminocyclopropane-1-carboxylate (ACC) deaminase, which converts ACC into $\alpha$-ketobutyrate and ammonia. ACC deaminase is encoded by some bacteria, can reduce the amount of ethylene, a root elongation inhibitor, and stimulate the growth of plants 
under various environmental stresses. The presence of ACC deaminase activity and the regulation of ACC in several bacteria have been reported (Han et al., 2015). Cellulases are the inducible bioactive compounds produced by microorganisms during their growth on cellulosic matter. Cellulose degrading enzymes encoded by microorganism are of great interest as they play key role in global carbon cycling. The cellulolytic property of some bacterial genera such as Cellulomonas sp, Pseudomonas sp, Bacillus sp and Micrococcus sp. was also reported (Susilowati et al., 2015). The aim of the study was to analyze Pseudomonas sp. for plant growth promoting (PGP) characteristics and role in colonization to be exploit as future biofertilizer in rice.

\section{MATERIALS AND METHODS}

Isolation of endophytic bacteria: Healthy plants were carefully removed, washed under tap water to remove soil. Surface sterilization of leaf and root issue was done with standard protocol (Muangthong et al., 2015). On Pseudomonas agar media for the isolation of endophytic Pseudomonas sp. $10^{-6}$ dilution $(100 \mu \mathrm{l})$ of macerated tissue was used and incubated at $28 \pm 2{ }^{\circ} \mathrm{C}$ for 2 3 days.

Characterization of endophytic bacteria for multifunctional traits:

Quantitative analysis of indole acetic acid (IAA) production: Endophytic bacterial isolates were grown in Luria Bertanni broth containing tryptophan $0.01 \%$ (L-Trp) and incubated at $28 \pm 2{ }^{\circ} \mathrm{C}$ (BOD incubator) for 3-6 days. IAA production was estimated by Gordon and Weber, (1971) using Salkowski's reagent (1 ml of $0.5 \mathrm{MFeCl}_{3}$ in $50 \mathrm{ml}$ of $35 \% \mathrm{HClO}_{4}$ ). Absorbance of pink colour was measured spectroscopically at $535 \mathrm{~nm}$ in UV-Visible Spectrophotometer (ELICO). The unknown strength was measured with help of standard curve.

Qualitative estimation of phosphate solubilization: P solubilization ability of endophytic bacteria was determined qualitatively by spot inoculating the cultures with the help of inoculating needle on NBRIP (National Botanical Research Institute's Phosphate growth) medium under aseptic conditions (Arora, 2007). Presence of yellow clear halo zone around bacterial growth after 5-7 days of incubation at $28 \pm 2{ }^{\circ} \mathrm{C}$ was used as indicator for positive $\mathrm{P}$ solubilization. Phosphate solubilization index (PSI) was calculated by using following formula:

PSI Index $=\mathrm{A} / \mathrm{B}$

$\mathrm{A}=$ Total diameter (colony + halo zone)

$\mathrm{B}=$ Diameter of colony

Quantitative measurement of phosphate solubilization: Promising P-solubilizers were tested for quantitative phosphate solubilization. Pikovaskaya's broth was amended with tri-calcium phosphate (TCP) as an inorganic phosphate substrate and were inoculated with culture and incubated at $28 \pm 2{ }^{\circ} \mathrm{C}$ for 15 days. P- solubilization activity was recorded at the interval of 3 days. Presence of yellow colour after addition of ammonium molybdate and ammonium vandate in equal ratio to culture supernatant confirmed phosphate solubilizing activity. Yellow colour intensity of the solution was measured with UV-VIS spectrophotometer (ELICO) at $420 \mathrm{~nm}$ after 25 minutes incubation (Jackson,1973). The unknown strength of yellow colour solution was estimated with help of standard curve using $\rho$-nitrophenol as a standard.

Siderophore production: Endophytic bacterial isolates were assayed for qualitative siderophore production on the Chrome azurol succinate (CAS) agar medium described by Schwyn and Neilands (1987) with $\mathrm{FeCl}_{3}$ as an inorganic source of $\mathrm{Fe}$. CAS agar plates were spot inoculated with test organism and incubated at $28 \pm 2{ }^{\circ} \mathrm{C}$ for 3-6 days. Development of yelloworange halo zone around the culture spot was considered as positive for siderophore production.

Qualitative estimation of ACC deaminase production: The qualitative estimation was done as per method of Govindasamy et al. (2008). Endophytic bacterial isolates were streaked on plates containing Dworkin Foster (DF) minimal medium with ACC as a sole nitrogen source. The plates were incubated for 3-4 days at $28 \pm 1{ }^{\circ} \mathrm{C}$ and observed for growth. Presence of culture growth on DF minimal medium was considered as positive for ACC deaminase production.

Quantitative estimation of ACC-deaminase production: Endophytic bacterial isolates were grown in liquid DF minimal medium with ACC as sole source of nitrogen. Growth of endophytic bacterial isolates in medium was measured at $600 \mathrm{~nm}$ using a Tech Comp UV-VIS Spectrophotometer (Shahzad et al., 2010).

Protease production: Protease activity was determined by spot inoculation of test organism on skimmed milk agar medium plates, incubated at $28 \pm 2{ }^{\circ} \mathrm{C}$ for $2-5$ days. Development of halo clear zone around the colony was considered as positive for protease production (Chaiharn et al., 2008). The diameter of halo clear zone was recorded.

Cellulase production: Endophytic bacterial isolates were screened for cellulase activity by spot inoculation on Carboxy Methyl Cellulose (CMC) agar medium. Plates were incubated at $28 \pm 2{ }^{\circ} \mathrm{C}$ for 5 days. After incubation, the agar plates were treated with an aqueous solution of Congo red $(1 \% \mathrm{w} / \mathrm{v})$ for 15 minutes according to Ariffin et al. (2006). Congo red solution was then poured off and plates were further treated by flooding with $1 \mathrm{M} \mathrm{NaCl}$ for 15 minutes. Formation of a clear zone of hydrolysis indicated cellulose degradation. The diameter of clear zone was measured in order to select the isolates with high cellulase activity.

Fluorescent pigment production: Endophytic bacterial isolates were spot inoculated on King's B medium and incubated at $28{ }^{\circ} \mathrm{C}$ for 2 days. Plates were observed under UV light to examine fluorescent ability. 
Presence of yellowish green colour indicated positive for fluorescent pigment production.

Urease test: A loopful of the endophytic bacterial isolates were aseptically inoculated into sterile Christensen's urea broth containing the $\mathrm{pH}$ indicator phenol red (Cappuccino and Sherman, 2002) and incubated at $30{ }^{\circ} \mathrm{C}$ for 24 hours. Development of pink colour was considered as positive test.

Denitrification test: The endophytic bacterial isolates were aseptically inoculated into sterile nitrate reduction broth containing Durham's tubes and incubated at $28 \pm 2^{\circ} \mathrm{C}$ for 72 hours. Durham's tubes containing bubble were considered as positive test.

Intrinsic antibiotic spectra: The endophytic bacterial isolates were grown in the nutrient agar (NA) medium plates containing a particular antibiotic with particular concentration viz.ampicillin (2, 10 and $25 \mu \mathrm{g} / \mathrm{disc})$, chloramphenicol $(10,30$ and $50 \mu \mathrm{g} / \mathrm{disc})$, streptomycin $(10,25$ and $300 \mu \mathrm{g} /$ disc) and erythromycin $(5,10$ and $15 \mu \mathrm{g} /$ disc). Multiple antibiotic markers were prepared for different endophytes on the basis of resistance to particular antibiotic (Kumar et al., 2013).

Screening of potential endophytic bacteria for colonization study:

Colonization study: Seeds of rice were surface sterilized according to standard protocol

(Muangthong et al., 2015) kept for germination on $1 \%$ agar petriplate for $24 \mathrm{~h}$ at $28 \pm 2{ }^{\circ} \mathrm{C}$ in a B.O.D incubator. Soil was autoclaved ( 3 times) at $121{ }^{\circ} \mathrm{C}$ for 1 hour with interval of $48 \mathrm{~h}$. Germinated seedlings were transferred to sterilized disposable coffee cups containing soil and nitrogen free solution, along with 1-2 $\mathrm{ml}$ of broth of different endophytic bacterial isolates. These disposable coffee cup assemblies were kept in green house and watered daily with sterilized Slogar's nitrogen free watering solution. Each treatment had three replications. After 20days, plants were analyzed for root colonization by endophytic bacteria using specific antibiotic marker containing NA plates (Giri et al., 2013).

\section{RESULTS AND DISCUSSION}

Total 10 endophytic bacterial isolates (LRBRE4, LRBRE5, LRBRE6, LRBRE7, LRBRE8, LRBRE9, LRBLE5, LRBLE6, LRBLE7 and LRBLE8) from rice root and leaf sample were isolated and streaked over the Pseudomonas agar medium incubated at $28 \pm 2{ }^{\circ} \mathrm{C}$. Further endophytic bacterial isolates were maintained on Pseudomonas agar medium, stored at $4{ }^{\circ} \mathrm{C}$ for further studies. Total 10 endophytic bacterial isolates were gram negative, rods and positive for catalase, oxidase and nitrate reduction. On the basis of morphology and biochemical characterization, these endophytic bacterial isolates were tentatively assigned to genera Pseudomonas.

Quantitative screening of IAA production: All the endophytic isolates of Pseudomonas sp produced pink colouration for quantitative analysis in Luria broth supplemented with $0.01 \%$ tryptophan. The amount of IAA was ranged from $9.5-18.8 \mu \mathrm{gml}^{-1}$ after the incubation of 3 days (Table 1). Maximum IAA production was recorded with isolate LRBLE7 $\left(18.8 \mu \mathrm{gml}^{-1}\right)$ followed by LRBRE4 (16.0 $\left.\mathrm{ggml}^{-1}\right)$, LRBRE6 (15.8 $\mathrm{ggml}^{-1}$ ) (Fig 1). These results are in close agreement with Ji et al. (2014) who stated that among 12 endophytic bacterial isolates, 10 were able to produce high level of IAA ranging from 11 to 24.6 $\mu \mathrm{gml}^{-1}$, while two isolates (KW7-R08 and CB-S18)

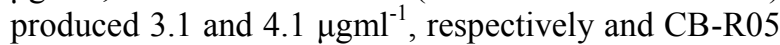
was found to produce highest amount of IAA (24.6 $\left.\mu \mathrm{gml}^{-1}\right)$. Many bacteria are capable of producing indolic compounds in the presence of precursor amino acid tryptophan (Trp). However, availability of Trp varies with the host plant (Sethia et al., 2014). Similarly, Loaces et al. (2011) also stated that the ability to produce IAA was extremely variable among the endophytic bacteria, suggesting that the production of IAA is strain dependent.

Qualitative estimation of phosphate solubilization: Out of 10 endophytic Pseudomonas sp. , 3 (LRBRE4, LRBRE6 and LRBLE7) isolates were selected on the basis of formation of clear halo zone around the bacterial colony considered as positive for P-solubilization. Based on the diameter of halo zone, Phosphate solubilizing index (PSI) was calculated on NBRIP medium. PSI of LRBRE4, LRBRE6 and LRBLE7 were 1.09, 1.08 and 1.09 respectively. Our results are in concordance with Rangjaroen et al. (2015) who reported out of 396 endophytic diazotrophic bacterial (EDB) isolates from the different tissues (mature seeds, leaves, stems and roots) of rice $85.71 \%$ (340) were able to solubilized calcium phosphate. Highest phosphate solubilization (PS) index (2.24) was observed in isolate TR5.

Quantitative measurement of phosphate solubilization: P-solubilization of different endophytic Pseudomonas sp. was measured at different time interval (3, $6,9,12$ and 15 days). P-solubilization ranged from 3.2 $-5.8 \mathrm{mg} 100 \mathrm{ml}^{-1}$ at $12^{\text {th }}$ day (Table 1). Maximum Psolubilization was recorded with isolate LRBRE4 (5.8 $\mathrm{mg} 100 \mathrm{ml}^{-1}$ ) followed by LRBLE7 (4.4 mg $100 \mathrm{ml}^{-1}$ ), LRBRE6 (3.2 mg $100 \mathrm{ml}^{-1}$ ) (Fig. 2). These results are in harmony with Sharma et al. (2015) who reported that out of 120 fluorescent pseudomonads isolates obtained from rhizosphere of green gram (Vigna radiata L.), only $8.3 \%$ (10) were able to solubilize phosphorous in Pikovaskaya's broth amended with tri-calcium phosphate (TCP) and highest amount of P-solubilization was ob-

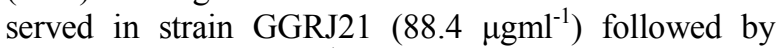
GGRJ $30\left(66.66 \mu \mathrm{gml}^{-1}\right)$.Acidification caused with organic acid production (oxalic acid, gluconic acid etc.) by microbes leads to transform the insoluble $\mathrm{P}$ into soluble form of $\mathrm{P}$. Production of different organic acids by the phosphate solubilizers strain can contribute to the greater potential for solubilization of insoluble 
Table 1. Assessment of PGP traits in endophytic bacterial isolates of rice.

\begin{tabular}{|c|c|c|c|}
\hline Endophytic bacterial isolates & $\begin{array}{l}\text { IAA production }\left(\mu \mathrm{gml}^{-1}\right) \text { at } \\
3^{\text {rd }} \text { day }\end{array}$ & $\begin{array}{l}\text { P-solubilization }(\mathrm{mg100ml} \\
\left.{ }^{1}\right) \text { at } 12^{\text {th }} \text { day }\end{array}$ & $\begin{array}{l}\text { ACC deaminase pro- } \\
\text { duction }(O . D \text { at600 } \mathrm{nm})\end{array}$ \\
\hline LRBRE4 & 16 & 5.8 & - \\
\hline LRBRE5 & 13.2 & - & 0.324 \\
\hline LRBRE6 & 15.8 & 3.2 & - \\
\hline LRBRE7 & 9.5 & - & - \\
\hline LRBRE8 & 11.4 & - & - \\
\hline LRBRE9 & 11.4 & - & - \\
\hline LRBLE5 & 13.4 & - & - \\
\hline LRBLE6 & 11.5 & - & 0.352 \\
\hline LRBLE7 & 18.5 & 4.4 & - \\
\hline LRBLE8 & 13.1 & - & - \\
\hline
\end{tabular}

- Negative

Table 2. Screening of endophytic bacterial isolates for intrinsic antibiotic resistancespectraof rice.

\begin{tabular}{|c|c|c|c|c|c|c|c|c|c|c|c|c|}
\hline \multirow{2}{*}{$\begin{array}{l}\text { Potential endo- } \\
\text { phytic bacterial } \\
\text { isolates }\end{array}$} & \multicolumn{12}{|c|}{ Zone of inhibition $(\mathrm{cm})^{*}$} \\
\hline & $\begin{array}{l}\text { AMP } \\
2 \mu \mathrm{g}\end{array}$ & $\begin{array}{l}\text { AMP } \\
25 \mu \mathrm{g}\end{array}$ & $\begin{array}{l}\text { AMP } \\
30 \mu \mathrm{g}\end{array}$ & $\begin{array}{l}\text { C } 10 \\
\mu \mathrm{g}\end{array}$ & $\begin{array}{l}\text { C } 30 \\
\mu \mathrm{g}\end{array}$ & $\begin{array}{l}\text { C } 50 \\
\mu \mathrm{g}\end{array}$ & $\begin{array}{l}S \quad 10 \\
\mu \mathrm{g}\end{array}$ & $\begin{array}{l}\text { S } 25 \\
\mu \mathrm{g}\end{array}$ & $\begin{array}{l}S \quad 300 \\
\mu \mathrm{g}\end{array}$ & $\begin{array}{l}\mathbf{E} \\
\mathbf{5} \\
\mu \mathrm{g}\end{array}$ & $\begin{array}{l}\text { E } 10 \\
\mu \mathrm{g}\end{array}$ & $\begin{array}{l}\text { E } 15 \\
\mu \mathrm{g}\end{array}$ \\
\hline LRBRE 4 & $\overline{\mathrm{R}}$ & 0.5 & 0.5 & 1.5 & 2 & 2.2 & 2 & 1.8 & 2 & 1.8 & 2.1 & 1.9 \\
\hline LRBRE 6 & $\mathrm{R}$ & 1.5 & 1.5 & 1.8 & 2.1 & 2.5 & 2.1 & 2.1 & 2.2 & 2.1 & 2.5 & 2.3 \\
\hline LRBLE 7 & $\mathrm{R}$ & 0.5 & 0.6 & 1.5 & 1.8 & 2.2 & 1.7 & 2 & 1.7 & 1.8 & 2 & 2.2 \\
\hline
\end{tabular}

R- Resistence, * concentration ( $\mu \mathrm{g} / \mathrm{disc})$

Table 3. Cell wall degrading enzymes and fluorescent pigment production by endophytic bacterial isolates.

\begin{tabular}{|c|c|c|c|}
\hline Endophytic bacterial isolates & $\begin{array}{l}\text { Protease } \\
\text { (halo zone } \\
\text { diameter) }\end{array}$ & $\begin{array}{l}\text { Cellulase } \\
\text { (halo zone } \\
\text { diameter) }\end{array}$ & Fluorescent pigment production \\
\hline LRBRE4 & - & - & + \\
\hline LRBRE5 & - & - & + \\
\hline LRBRE6 & - & - & - \\
\hline LRBRE7 & - & - & + \\
\hline LRBRE8 & $1.3 \mathrm{~cm}$ & - & - \\
\hline LRBRE9 & $1.2 \mathrm{~cm}$ & - & - \\
\hline LRBLE5 & $2.0 \mathrm{~cm}$ & - & + \\
\hline LRBLE6 & $1.0 \mathrm{~cm}$ & - & + \\
\hline LRBLE7 & $1.2 \mathrm{~cm}$ & $1.0 \mathrm{~cm}$ & + \\
\hline LRBLE8 & $1.0 \mathrm{~cm}$ & $0.8 \mathrm{~cm}$ & + \\
\hline
\end{tabular}

+ Zone, - No zone

inorganic phosphates (TCP) (Khan et al., 2014).

Siderophore production: Out of 10 endophytic Pseudomonas sp. 3 (LRBRE4, LRBLE5 and LRBLE8) were able to show development of orange halo zone on chrome azurol succinate (CAS) agar medium amended with ferric chloride after 5 days of incubation. Similarly, Naureen et al.(2015) also documented that out of 63 bacterial isolates from the rhizosphere and rhizoplane of rice and maize plants, 20 were found positive for siderophore production on CAS medium. Siderophore production indicates strong biocontrol capacities allowing competition with pathogens for iron, as suspected for some cultured endophytes (Sessitsch et al., 2015).

Qualitative estimation of ACC deaminase production: Of 10 endophytic Pseudomonas sp. 2 (LRBRE5 and LRBLE6) were able to grow on Dworkin Foster (DF) minimal medium with ACC as a sole nitrogen source at $28 \pm 1^{\circ} \mathrm{C}$ after 3 days. Our results are well coherent with Singh and Jha, (2015) who reported strain AJS-15 isolated from rhizosphere of Aervajavanica was positive for ACC deaminase activity. PGP bacteria stimulate plant growth by the activity of ACC deaminase by decreasing plant ethylene level. Thereby, reducing the suppressive effect of ethylene on root elongation and thus promoting plant growth (Glick, 2014).

Quantitative estimation of ACC-deaminase production: Endophytic Pseudomonas sp. positive for qualitative test were assessed to quantitative ACC deaminase measurement in liquid DF minimal medium 


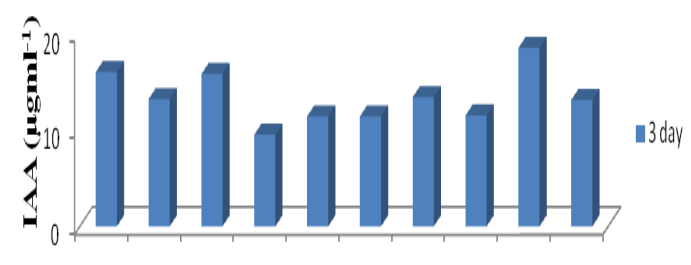

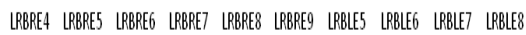

\section{Endophtichlacterialisolates}

Fig. 1. Quantitative IAA production by endophytic bacterial isolates of rice.

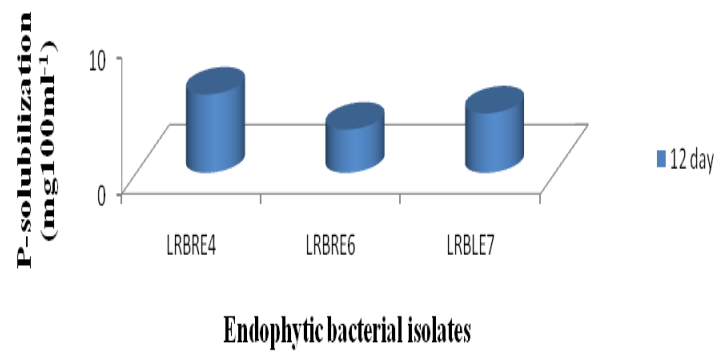

Fig. 2. Quantitative P-solubilization of endophytic bacterial isolates of rice.
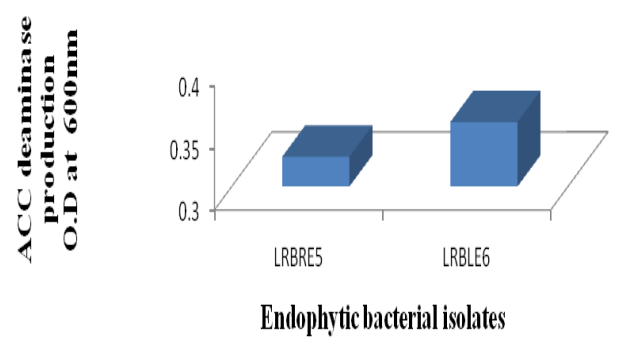

Fig. 3. Quantitative ACC deaminase production by endophytic bacterial isolates of rice.

with ACC as sole source of nitrogen. After 3 day of incubation, growth of endophytic bacterial isolates LRBRE5 and LRBLE6 were O.D $=0.324 \mathrm{~nm}$ and $\mathrm{O} . \mathrm{D}=0.352 \mathrm{~nm}$ respectively (Fig 3 ). Our results are in harmony with Ali et al.(2014) who also observed nine drought tolerant isolates, from rhizospheric soil of different crop production system, for ACC deaminase activity, among these isolates only SorgP4 isolate showed positive for ACC deaminase activity $(42 \pm 0.039 \mu \mathrm{M} / \mathrm{mg}$ protein $/ \mathrm{h})$.

Protease production: All 10 endophytic Pseudomonas sp. were tested for qualitative production of protease on skim milk agar medium. Of 10 isolates, $60 \%$ (6) were able to produce protease enzyme with development of clear zone on the skim milk agar medium (Table3). Maximum halo zone diameter was recorded with LRBLE5 $(2.0 \mathrm{~cm})$ followed by LRBRE8 $(1.3$ $\mathrm{cm})$, LRBRE9 $(1.2 \mathrm{~cm})$, LRBLE7 $(1.2 \mathrm{~cm})$, LRBLE6 and LRBLE8 $(1.0 \mathrm{~cm})$. Our results are supported by Singh and Jha, (2015) who observed that strain Enterobacter cloaceae isolated from Aervajavanica was positive for protease production. Proteases are hydrolytic enzymes that catalyze protein hydrolysis by cleaving the intra amino acid peptide bonds in protein molecules. Proteases produced by micro-organisms are of great importance in the biosynthesis, bioremediation and biotransformation (Shine et al., 2016).

Cellulase production: Total 10 isolates of endophytic Pseudomonas sp. were tested for qualitative production of cellulase enzymes and $20 \%$ (2) were able to produce cellulase enzyme with development of halo zone on CMC agar medium (Table 3). Maximum halo zone diameter was recorded by isolate LRBLE7 (1.0 $\mathrm{cm})$ followed by LRBLE8 $(0.8 \mathrm{~cm})$. Similarly, Susilowati et al. (2015) also reported that among 78 bacteria isolated from the rice rhizosphere, 33 isolates produced cellulase. Cellulose degrading microorganisms can convert cellulose into soluble sugars either by their acid and enzymatic hydrolysis. Thus microbial cellulose utilization is responsible for one of the largest material flows in the biosphere.

Fluorescent pigment production: All 10 endophytic Pseudomonas sp. were grown on King's B medium specific for fluorescence pigment production under UV light. Of 10 isolates $70 \%$ (7) were found to be putative fluorescent pigment producers (Table 3). Our result are in accordance with Hung et al. (2007) who reported that out of 65 isolates grown on King's B medium, seven isolates were putative fluorescent pigment producers. Fluorescent Pseudomonas sp. has plant growth-promoting effects through effective suppression of soil borne plant diseases. Among various biocontrol agents, fluorescent Pseudomonas sp. equipped with multiple mechanisms for biocontrol of phytopathogens (Saharan and Nehra, 2011).

Urease production: All 10 endophytic Pseudomonas sp. were screened for urease activity in Christensen's urea broth amended with phenol red ( $\mathrm{pH}$ indicator). Out of 10 endophytic bacterial isolates, only isolate LRBLE8 was able to produce urease. Mbai et al. (2013) also showed that out of 73 endophytic bacterial isolates, from root of basmati rice, 47 isolate were positive for urease test. Urease production by bacteria is an important aspect for growth enhancement in rice as it converts urea to simpler forms of nitrogen forreadily absorbtionby plants (Mbai et al., 2013).

Denitrification activity: Total 10 endophytic Pseudomonas sp. were screened for denitrification activity in nitrate reduction broth with inverted Durham's tube to detect gas production. Isolate LRBRE9 was able to produce elemental $\mathrm{N}_{2}$ in inverted Durham's tube by denitrification activity. In flooded rice, denitrification occurs in the reduced soil layer due to non-availability of oxygen. It is not advisable to use denitrifiers as biofertilizer in rice as readily available forms of nitrogen 
can be converted into free $\mathrm{N}_{2}$ by denitrifying bacteria (Mbai et al., 2013).

Intrinsic antibiotic spectra: Out of 10 endophytic Pseudomonas sp. 3 isolates (LRBRE4, LRBRE6 and LRBLE7) were selected as potential endophytes on the basis of PGP traits for assessment of intrinsic antibiotic resistance (IAR) spectra. All endophytic bacterial isolates were resistant to ampicillin antibiotic at concentration $2 \mu \mathrm{g} /$ disc but highly susceptible to antibiotics like chloramphenicol (10 and $30 \mu \mathrm{g} / \mathrm{disc}$ ), streptomycin (10 and $25 \mu \mathrm{g} / \mathrm{disc}$ ) and erythromycin (5 and 10 $\mu \mathrm{g} / \mathrm{disc})$. Our results are in close agreement with Gopalakrishnan et al. (2012) who also reported all seven bacteria (SRI-156, SRI-158, SRI-178, SRI-211, SRI229, SRI-305 and SRI-360) isolated from the rhizosphere of rice were resistant to ampicillin but highly sensitive $(<10 \mathrm{ppm})$ to chloramphenicol, kanamycin, nalidixic acid, streptomycin (except SRI-156 and SRI211) and tetracycline.

Colonization study: All 3 potential endophytic Pseudomonas sp. were screened for resistance to antibiotic ampicillin to be used as marker for colonization studies of rice root under sterilized conditions. All endophytic bacterial isolates were able to grow on ampicillin at concentration $2 \mu \mathrm{g} / \mathrm{disc}$ as a marker for colonization study in rice root. Each endophyte was grown on NA medium plates containing ampicillin antibiotic marker. During isolation of bacteria from root of rice three control plates were kept without any inoculation. At $20^{\text {th }}$ day of inoculation, all 3 potential endophytic bacterial isolates were detected in rice roots for colonization on ampicillin antibiotic marker containing NA plates with three replications. Colonization of rice seedling by endophytic bacteria ranged from 2.89-3.15 $\log$ cfu per $g$ root fresh weight. Highest colonization was detected in endophytic bacterial isolate LRBRE6 (3.15 log cfu per $\mathrm{g}$ root fresh weight) followed by LRBRE4 (3.09 log cfu per g root fresh weight), LRBLE7 (2.89 log cfu per g root fresh weight). Similarly, Giri et al. (2013) also reported that colonization studies in wheat at $15^{\text {th }}$ day and $30^{\text {th }}$ day of inoculation, none of the isolate was detected in wheat root but at $50^{\text {th }}$ day, four endophytic bacterial isolates i.e. LRE3, LRE7, WRE20 and ORE27 were detected on their respective antibiotic marker containing plates and maximum number $3.97 \log$ CFU per plant root of isolate ORE27 was observed.

\section{Conclusion}

This study demonstrated the occurrence of culturable endophytic Pseudomonas sp. in rice. On the basis of morphological, biochemical and multiple plant growth promoting traits LRBRE4, LRBRE6 and LRBLE7 were found as potential endophytic bacterial isolates. Significantly high IAA production was observed in isolate LRBLE7 $(18.5 \mu \mathrm{g} / \mathrm{ml})$. Highest P-solubilization $(5.8 \mathrm{mg} / 100 \mathrm{ml})$ and PSI (1.09) was recorded in isolate
LRBRE4. Secretion of protease and cellulase enzymes makes the entry of endophytic bacteria into the plant tissue much easier for colonization. Maximum protease production was recorded with LRBLE5 $(2.0 \mathrm{~cm})$ and cellulase production in isolate LRBLE7 $(1.0 \mathrm{~cm})$. Highest colonization was observed in isolate LRBRE6 (3.15 log cfu per g root fresh weight). Thus, it is obvious from this investigation that the Pseudomonas sp.with PGP traits (in vitro) can be explored for development of bioinoculants in improving rice productivity.

\section{REFERENCES}

Ali, S. Z., Sandhya, V. and Rao, L. V. (2014). Isolation and characterization of drought tolerant ACC deaminase and exopolysaccharide producing fluorescent Pseudomonas sp. Ann. Microbiol., 64: 493-502

Ariffin, H., Abdullah, N. K., Umi, Y., Shirai, Y. and Hassan, M. A. (2006). Production and characterization by Bacillus pumilus EB3. Int. J. Engg. Sci. Technol., 3: 47-53

Arora, D. K. (2007). Microbial identification modules for some agriculturally important micro-organism Pp 97107 National Bureau of Agriculturally important microorganism (NBAIM) Mau U.P.

Cappuccino, J. G. and Sherman, N. (2002). Microbiology: a laboratory manual (6th ed) Pearson.

Chaiharn, M., Chunhaleuchanon, S., Kozo, A. and Lumyong, S. (2008). Screening of rhizobacteria for their plant growth promoting activities. J. Kmitl. Sci. Technol., 8: $18-23$

Giri, R. and Dudeja, S. S. (2013). Host specificity of plant endophytic bacterial interactions Root and nodule colonization under sterilized sand conditions in disposable coffee cups. Cent. Eur. J. Exp. Biol., 2(4): 22-26

Glick, B. R. (2014). Bacteria with ACC deaminase can promote plant growth and help to feed the world. Microbiol. Res., 169:30-39

Gopalakrishnan, S., Upadhyaya, H. D., Vadlamudi, S., Humayun, P., Vidya, M. S., Alekhya, G., Singh, A., Vijayabharathi, R., Bhimineni, R. K., Seema, M., Rathore, A. and Rupela, O. (2012). Plant growth promoting traits of biocontrol potential bacteria isolated from rice rhizosphere. Springer Plus 1: 71

Gordon, A. S. and Weber, R. P. (1951). Colorometric estimation of indol acetic acid. Plant Physiol., 26: 192-195

Govindasamy, V., Kumar, S. M., Kumar, U. and Annapurna, K. (2008). PGPR Biotechnology for management of abiotic and biotic stresses in crop plants. Maheshwari, D. K., and Dubey, R. C. (Eds) Potential microorganisms for sustainable agriculture I K International Publication. India. Pp 26-48

Han, Y., Wang, R., Yang, Z., Zhan, Y., Ma, Y. and Ping, S. (2015). 1-Aminocyclopropane-1-Carboxylate deaminase from Pseudomonas stutzeri A1501 facilitates the growth of rice in the presence of salt or heavy metals. $J$. Microbiol. Biotechnol., 25:1119-1128

Hung, P. Q., Kumar, S. M., Govindsamy, V. and Annapurna, K. (2007). Isolation and characterization of endophytic bacteria from wild and cultivated soybean varieties. Biol. Fertil. Soils, 44: 155-162

Jackson, M. L. (1973). Estimation of phosphorus content Soil chemical analysis Printer Hall New Delhi (India).

Ji, S. H., Gururani, M. A. and Chun, C. S. (2014). Isolation 
and characterization of plant growth promoting endophytic diazotrophic bacteria from Korean rice cultivars. Microbiol. Res., 169: 83-98

Khan, M. S., Zaidi, A. and Ahmad, E. (2014). Mechanism of phosphate solubilization and physiological functions of phosphate solubilizing microorganisms. (ed) Phosphate Solubilizing microorganisms. Pp. 31-62

Kumar, U., Kumar, V. L. and Annapurna, K. (2013). Antagonistic potential and functional diversity of endo and rhizospheric bacteria of basmati rice. Oryza, 50: 162168

Loaces, I., Ferrando, L. and Scavino, A. F. (2011). Dynamics, diversity and function of endophytic siderophore producing bacteria in rice. Microb. Ecol., 61:606-618

Mbai, F. N., Magiri, E. N., Matiru, V. N. and Nyambati, V. C. S. (2013). Isolation and characterisation of bacterial root endophytes with potential to enhance plant growth from Kenyan basmati rice.Am. Int. J. Contem. Res., 3: $25-40$

Muangthong, A., Youpensuk, S. and Rerkasem, B. (2015). Isolation and characterisation of endophytic nitrogen fixing bacteria in sugarcane. Trop. Life Sci. Res., 26(1): $41-51$

Naureen, Z., Hafeez, F. Y., Hussain, J., Harrasi, A. A., Bouqellah, N. and Roberts, M. R. (2015). Suppression of incidence of Rhizoctoniasolani in rice by siderophore producing rhizobacterial strains based on competition for iron. Eur. Sci. J., 11: 186-207

Panhwar, Q. A., Othman, R., Rahman, Z. A., Meon, S. and Ismail M. R. (2012). Isolation and characterization of phosphate solubilizing bacteria from aerobic rice. Afr. J.Biotechnol., 11: 2711-2719

Rangjaroen, C., Rerkasem, B., Teaumroong, N., Sungthong, R. and Lumyong, S. (2014). Comparative study of endophytic and endophytic diazotrophic bacterial communities across rice landraces grown in the highlands of Northern Thailand. Arch. Microbiol., 196: 35-49

Romero, F. M., Marina, M. and Pieckenstain, F. L. (2014). The communities of tomato (Solanum lycopersicum L.) leaf endophytic bacteria analyzed by $16 \mathrm{~S}$ ribosomal RNA gene pyrosequencing. F.E.M.S. Microbiol. Lett., 351: 187-194

Saharan, B. S. and Nehra, V. (2011). Plant growth promoting rhizobacteria: a critical review. Life Sci. Medicine Res. 21: $1-30$

Schwyn, B. and Neilands, J. B. (1987). Universal assay for the detection and determination of siderophores. Anal. Biochem., 160: 47-56

Sessitsch, A., Hardoim, P., Döring, J., Weilharter, A., Krause, A., Woyke, T., Mitter, B., Lotte, L. H., Friedrich, F., Rahalkar, M., Hurek, T., Sarkar, A., Bodrossy, L., Overbeek, L. V., Brar, D., Elsas, J. D. V. and Hurek, B. R. (2015). Functional characteristics of an endophyte community colonizing rice roots as revealed by metagenomic analysis. Mol. Plant. Microbe. Interact., 25: 28 $-36$

Sethia, B., Mustafa, M., Manohar, S., Patil, S. V., Jayamohan, N. S. and Kumudini, B. S. (2014). Indole acetic acid production by fluorescent Pseudomonas sp. from the rhizosphere of Plectranthus amboinicus (Lour.) Spreng and their variation in extragenic repetitive DNA sequences. Indian J. Exp. Biol., 53: 342-349

Shahzad, S. M., Khalid, A., Arshad, M. and Rehman, K. U. (2010). Screening rhizobacteria containing ACCdeaminase for growth promotion of chickpea seedlings under axenic conditions. Soil. Environ., 29(1): $38-46$

Shine, K., Kanimozhi, K., Panneerselvam, A., Muthukumar, C. and Thajuddin, N. (2016). Production and optimization of alkaline protease by Bacillus cereus RS3 isolated from desert soil. Int. J. Adv. Res. Biol. Sci., 3(7): 193202

Singh, R. P. and Jha, P. N. (2015). Plant Growth Promoting Potential of ACC Deaminase Rhizospheric Bacteria Isolated from Aervajavanica a Plant adapted to Saline environments. Int. J. Curr. Microbiol. App. Sci., 4(7): $142-152$

Souza, R. D., Beneduzi, A., Ambrosini, A., Costa, P. B., Meyer, J., Vargas, L. K., Schoenfeld, R. and Passaglia, L. M. P. (2013). The effect of plant growth promoting rhizobacteria on the growth of rice (Oryza sativa L.) cropped in southern Brazilian fields. Plant Soil, 366: 585-603

Susilowati, D. N., Sudiana, I. M., Mubarika, N. R. and Suwanto, A. (2015). Species and functional diversity of rhizobacteria of rice plant in the coastal soils of Indonesia. Indo. J. agri. Sci., 16: 39-50 